\title{
Carcinoid of the gallbladder in two dogs
}

\section{Fernando Froner Argenta ${ }^{1}$ (ID) Paula Reis Pereira ${ }^{1}$ (D) Marianna Bertolini ${ }^{1}$ Letícia Mendes Fratini $^{2}$ Renata de Oliveira Saccaro ${ }^{3}$ Luciana Sonne $^{1}$ David Driemeier ${ }^{1}$ (D) Saulo Petinatti Pavarini ${ }^{*}$ (D)}

${ }^{1}$ Setor de Patologia Veterinária, Faculdade de Veterinária, Universidade Federal do Rio Grande do Sul (UFRGS), 91540-000, Porto Alegre, RS, Brasil. E-mail: sauloppvet@yahoo.com.br. "Corresponding author.

${ }^{2}$ Hospital de Clínicas Veterinárias, Faculdade de Veterinária, Universidade Federal do Rio Grande do Sul (UFRGS), Porto Alegre, RS, Brasil. ${ }^{3}$ Hospital Veterinário Dra. Renata Saccaro, Caxias do Sul, RS, Brasil.

ABSTRACT: A carcinoid is a rare neoplasm derived from neuroendocrine cells that may arise in the hepatobiliary system. This report described two cases of carcinoid of the gallbladder in dogs, with emphasis on the clinical, pathological and immunohistochemical aspects. Case 1 was a 10-year-old female Shih Tzu, with a history of prostration and occasional episodes of diarrhea and vomiting. Case 2 was a 10-year-old male Cocker Spaniel, with a history of diarrhea and abdominal pain. Abdominal ultrasonography suggested a neoplasm of the gallbladder in both cases. The dogs underwent cholecystectomy, and 10\% formalin-fixed samples were sent for pathological examination. Histologically, a neoplastic proliferation of neuroendocrine cells was observed in the gallbladder submucosa of both cases. Immunohistochemical labeling for neuroendocrine antibodies, such as synaptophysin, neuron-specific enolase and chromogranin A, confirmed the diagnoses. Carcinoid of the gallbladder is a rare neoplasm in dogs, without specific clinical signs, but should be included in the differential diagnosis of lesions that affect this organ.

Key words: canine, neoplasm, neuroendocrine carcinoma, immunohistochemistry.

Carcinoide de vesícula biliar em dois cães

RESUMO: Carcinoide é um neoplasma raro derivado de células neuroendócrinas, que pode surgir no sistema hepatobiliar. Este relato descreve dois casos de carcinoide da vesícula biliar em cães, com ênfase nos aspectos clínicos, patológicos e imuno-histoquímicos. O caso 1 era uma fêmea, Shih Tzu de 10 anos de idade, com histórico de letargia e ocasionais episódios de diarreia e vômito. O caso 2 era um macho, Cocker Spaniel de 10 anos, que apresentava diarreia e dor abdominal. Através da ultrassonografia abdominal foi sugerida neoplasia na vesícula biliar em ambos os casos. Os caninos foram submetidos à colecistectomia e amostras em formol a 10\%, seguidamente, foram enviadas para o laboratório de patologia. Histologicamente, observou-se proliferação neoplásica de células neuroendócrinas na submucosa da vesícula biliar nos dois casos. A marcação imuno-histoquímica para os anticorpos neuroendócrinos, como sinaptofisina, enolase especifica de neurônios e cromogranina A confirmou o diagnóstico. Carcinoide de vesícula biliar é uma neoplasia rara em cães, sem sinais clínicos especificos, mas deve ser incluída no diagnóstico diferencial das lesões que afetam esse órgão.

Palavras-chave: canino, neoplasma, carcinoma neuroendócrino, imuno-histoquímica.

A carcinoid is neuroendocrine tumors arise from the neuroendocrine system, which are widely distributed in the body (CREUTZFELDT, 1996). This is a rare neoplasm in the hepatobiliary system, which may originate from the neuroendocrine cells of the liver and gallbladder (CULLEN, 2017). In humans, this type of neoplasm mainly affects the gastrointestinal tract, lungs and pancreas, and rarely affects the liver or gallbladder; it accounts for 0.2 to $1 \%$ of all neoplasms originating from neuroendocrine cells (CREUTZFELDT, 1996; NISHIGAMI et al., 1996; MODLIN et al., 2003).
Gallbladder neoplasms are infrequent in domestic animals and carcinoids that occur in this organ are rare in dogs, with limited cases described in the literature (CULLEN, 2017). Clinical signs are non-specific. However, anorexia, ascites, weight loss, diarrhea, and jaundice may be present (PATNAIK et al., 2005a); there are no specific changes in biochemical parameters that identify this type of tumor (CULLEN, 2017). The aim of this report was to describe two cases of carcinoid of the gallbladder in dogs with an emphasis on the clinical, pathological and immunohistochemical aspects. 
Case 1 was a 10-year-old Shih Tzu female with a history of prostration, occasional episodes of diarrhea and vomiting over a 10 -month period, and restlessness at night. During clinical examination, abdominal pain was observed upon palpation. The hemogram and leukogram did not reveal significant alterations. Biochemical analysis identified an increase in alanine aminotransferase (ALT) (158 U/1, reference value: $0-102 \mathrm{U} / \mathrm{l}$ ) and alkaline phosphatase (ALP) (243 U/1, reference value: 0-156 U/1) levels. Abdominal ultrasonography showed a thickening of the gallbladder wall with a rounded discrete heterogeneous echogenic formation adhered to the wall, measuring $2.0 \times 1.0 \mathrm{~cm}$, suggestive of neoplasm. The spleen showed a well-defined nodular area, measuring approximately $2.1 \times 0.9 \mathrm{~cm}$. Case 2 was a 10-year-old male Cocker Spaniel, who was referred to the veterinary hospital with a 1-month history of diarrhea and abdominal pain. The hemogram and leukogram did not reveal significant alterations Biochemical analysis identified an increase in ALT (182 U/1). Abdominal ultrasonography identified thickening of the gallbladder wall and a hypoechoic nodular structure adhered to the wall, measuring 2.0 $\mathrm{x} 1.5 \mathrm{~cm}$. Spleen size was moderately increased, containing a mass of mixed echogenicity, measuring $8.2 \times 5.9 \mathrm{~cm}$.

Both dogs underwent cholecystectomy and splenectomy. During the exploratory laparotomy, gross lesions were not identified in other organs. Ten-percent formalin-fixed gallbladder and spleen samples, of both cases, underwent histological examination and were stained using the hematoxylin and eosin (HE) technique. Gross evaluation of the gallbladder, in both cases, identified firm masses of well-defined borders, projecting into the lumen of the organ (case 1: $2.0 \mathrm{~cm} \times 1.5 \mathrm{~cm} \times 1.0 \mathrm{~cm}$, case 2: 2.0 $\mathrm{cm} \times 1.5 \mathrm{~cm} \times 1.5 \mathrm{~cm})$. On cut surface, the lesions were whitish firm, with yellow and slightly friable central areas (Figure 1A).

In both cases, microscopic analysis revealed delimited and un-encapsulated proliferation of neuroendocrine cells in the gallbladder submucosa, arranged in solid cords and trabeculae, supported by scarce fibrovascular stroma (Figure 1B). Neoplastic cells were rounded to polygonal, with indistinct cytoplasmic borders, pale with moderately granular eosinophilic cytoplasm, had round to oval central nuclei, with fine chromatin and evident nucleoli. The cells exhibited moderate anisocytosis and anisokaryosis, and an average of one mitotic figure was observed upon high-powered magnification (400X) (Figure 1C). Multifocal intra-tumoral areas of moderate hemorrhage and necrosis, as well as hyperplasia of the adjacent biliary epithelium, were also observed. The splenic lesion of case 1 was characterized microscopically as nodular hyperplasia, and that of case 2 as hemangiosarcoma. In case 2 , histological analysis of the adjacent liver parenchyma was performed, which identified discrete cholestasis and discrete periportal multifocal inflammatory infiltrate of lymphocytes and macrophages.

Histological findings of the canine gallbladders were compatible with carcinoid. To confirm the diagnoses, immunohistochemical (IHC) analyses was performed on serial sections of the neoplasms, using the peroxidase-labeled universal polymer method (MACH 4 Universal HRP-Polymer - Biocare Medical) for the following antibodies: neuron-specific enolase (NSE), S-100 protein, chromogranin A and synaptophysin. For cytokeratin 7 (CK7), Proteinase K (DakoCytomation) was used for antigen recovery. Table 1 shows the IHC antibodies and protocols used. Immunohistochemical analysis showed considerable diffuse intracytoplasmic immunoreactivity for synaptophysin in neoplastic cells, in both cases (Figure 1D). In case 1, there was also intense diffuse intracytoplasmic immunoreactivity for NSE in neoplastic cells (Figure 1D). In case 2, there was discrete intracytoplasmic labeling for chromogranin A in neoplastic cells. Immunoreactivity for CK7 and S-100 protein was not identified in either case.

Both dogs recovered well and were stable after 18 months (case 1) and 10 months (case 2) following surgery, and they underwent clinical follow-up with imaging and clinical evaluation. For case 2, a treatment protocol was established for splenic hemangiosarcoma with doxorubicin $30 \mathrm{mg} /$ $\mathrm{m}^{2}$ and a 21-day interval between each application. The owners have since reported occasional episodes of diarrhea in both cases.

Carcinoid is neuroendocrine tumors arise from the neuroendocrine system, which are widely distributed in the body (CREUTZFELDT, 1996), in the present cases originate from the neuroendocrine cells in the gallbladder mucosa (KAZUYOSHI et al., 1993; NISHIGAMI et al., 1996). Despite insufficient information regarding its epidemiological and clinical aspects (CULLEN, 2017), this neoplasm mainly affects elderly dogs (mean age approximately 9.5 years), as corroborated by the present study (PATNAIK et al., 1981; WILLARD et al., 1988; MORRELL et al., 2002). In the present study, the breeds affected were the Shih Tzu and the Cocker Spaniel. Current literature described cases in the Bullmastiff, Beagle, and Rhodesian ridgeback, in addition to two non- 


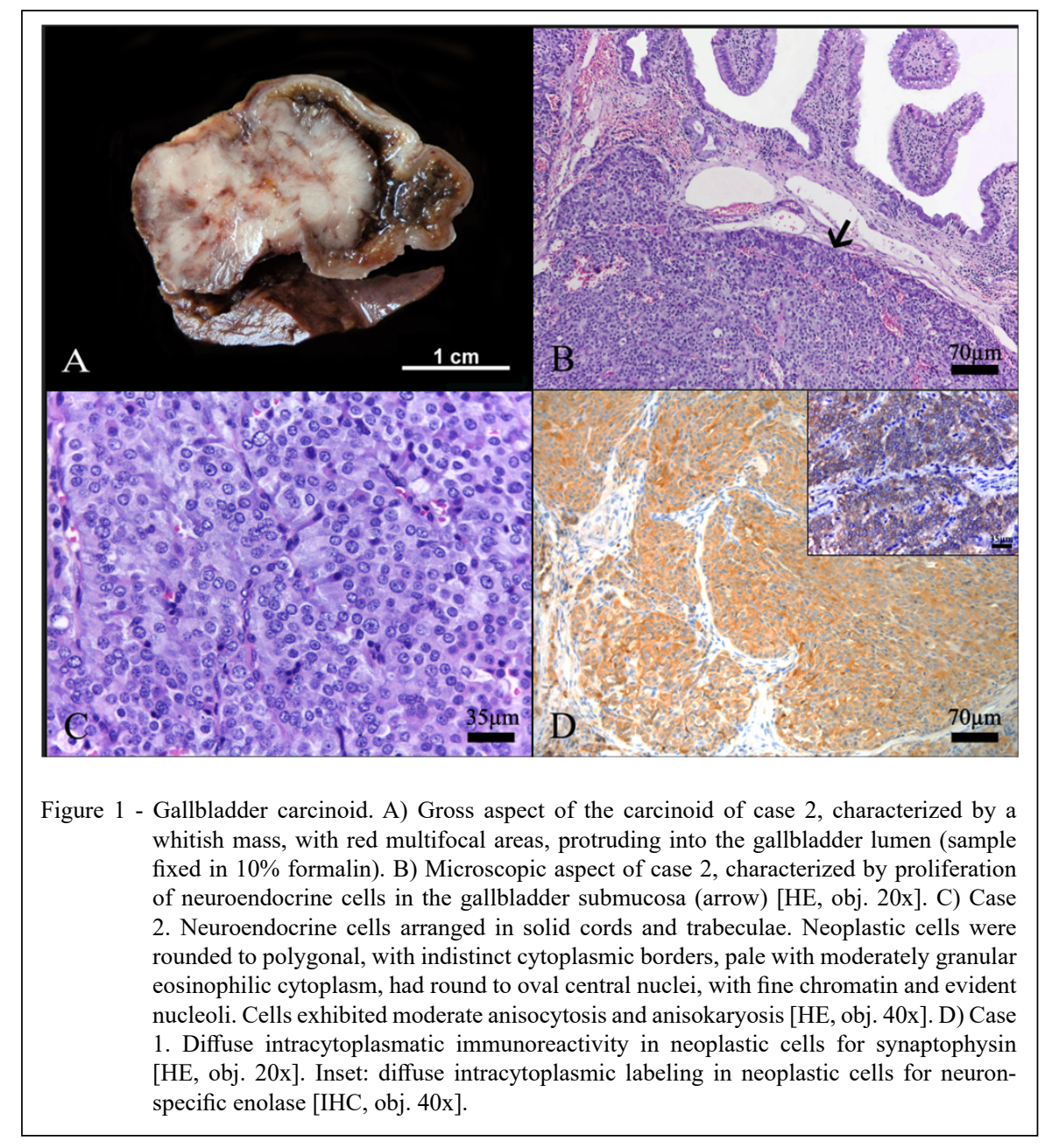

breed dogs (WILLARD et al., 1988; MORRELL et al., 2002; BIRETTONI et al., 2008; LIPPO et al., 2008). However, since gallbladder neoplasms are rare in dogs, and a limited number of cases are described in the literature, there is insufficient information to accurately associate predisposition with breed, age, or sex (CULLEN, 2017).

This type of neoplasm in the gallbladder is not related to specific clinical signs. However, anorexia, ascites, weight loss, diarrhea, jaundice, vomiting, abdominalgia and hematemesis was described in animals with carcinoids of the hepatobiliary system (PATNAIK et al., 1981; WILLARD et al., 1988; MORRELL et al., 2002; BIRETTONI et al., 2008; LIPPO et al., 2008). Dogs in the present study had a clinical history of prostration, diarrhea and vomiting, in addition to abdominal pain, but these findings may be related to the splenic tumor lesions, especially in case 2. In humans, carcinoid syndrome occurs in less than
$10 \%$ of patients with gastrointestinal carcinoids, and was caused by tumor secretion of hormones, mainly serotonin, into systemic circulation (TURNER, 2010). Typical clinical manifestations included skin flushing and diarrhea (HAMILTON et al., 1999). Researchers have reported diarrhea in a dog with carcinoid of the proximal jejunum, which may have been related to the excessive production of serotonin by neoplastic cells (SAKO et al., 2003). Diarrhea was one of the main clinical signs reported in the present study, but serum concentrations or IHC labeling was not performed to confirm an increase of this hormone.

Hepatobiliary carcinoids may show increased activity of liver enzymes, such as ALT and ALP (MORRELL et al., 2002; LIPPO et al., 2008). The increase in ALP in case 1 may be related to obstructive hepatic injury, due to neoformation, with a consequent decrease in biliary excretion of this enzyme (ALLISON, 2012). The increase of ALT in 
Table 1 - Antibodies and immunohistochemical protocols used in dogs with gallbladder carcinoids.

\begin{tabular}{|c|c|c|c|c|}
\hline Antibodies & Code & Dilution & Antigen Recovery & Chromogen \\
\hline Cytokeratin $7^{\mathrm{a}}$ & M3515 & $1: 80$ & Citrate Buffer $\mathrm{pH} 6.0$, pressure cooker $125^{\circ} \mathrm{C}, 3^{\prime}$ & $\mathrm{DAB}^{\mathrm{a}}$ \\
\hline Neuron-specific enolase ${ }^{a}$ & M0873 & $1: 200$ & Citrate Buffer $\mathrm{pH} 6.0$, pressure cooker $96^{\circ} \mathrm{C}, 40^{\prime}$ & DAB \\
\hline Synaptophysin ${ }^{\mathrm{b}}$ & ab8049 & $1: 50$ & Tris EDTA pH 9.0, pressure cooker $96^{\circ} \mathrm{C}, 20^{\prime}$ & $\mathrm{DAB}$ \\
\hline S-100 protein $^{a}$ & Z0311 & $1: 200$ & Citrate Buffer $\mathrm{pH} 6.0$, pressure cooker $96^{\circ} \mathrm{C}, 20^{\prime}$ & $\mathrm{AEC}^{\mathrm{a}}$ \\
\hline Chromogranin $\mathrm{A}^{\mathrm{a}}$ & A0430 & $1: 200$ & Citrate Buffer $\mathrm{pH} 6.0$, pressure cooker $96^{\circ} \mathrm{C}, 20^{\prime}$ & AEC \\
\hline
\end{tabular}

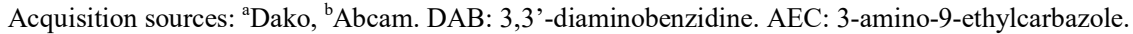

small animals indicated mainly hepatic damage, since it is specific for hepatocytes (ALLISON, 2012). In case 1 , no gross alteration was identified during laparotomy; although, no histological analyses were performed to identify a hepatocyte lesion that would justify the serum increase of this enzyme. Histological analysis showed a periportal inflammatory infiltrate in case 2 .

Carcinoids of the gallbladder do not present definitive gross characteristics that identify this type of tumor, when compared to other neoplasias affecting this organ. Friable and red multifocal areas can be identified and are related to necrosis and intratumoral hemorrhage, which corroborate the findings of the present study (CULLEN, 2017).

Microscopically, carcinoids of the present report are similar to those described in the literature, characterized by neuroendocrine cell proliferation, with formation of several solid cords supported by scarce fibrovascular stroma (MORRELL et al., 2002; CULLEN, 2017). Variation in histological patterns, such as formation of nests, ribbons, rosettes or a combination of more than one type, was commonly observed. Hyperplasia of the adjacent epithelium, hemorrhage and necrosis, are frequent features in carcinoids (MORRELL et al., 2002; CULLEN, 2017).

Immunoreactivity for synaptophysin (case 1 and 2), NSE (case 1), and chromogranin A (case 2) confirmed the diagnosis of carcinoid. These antibodies were frequently used for the definitive diagnosis of neuroendocrine neoplasms of the hepatobiliary system in humans, dogs and cats (ERICKSON \& LLOYD, 2004; PATNAIK et al., 2005a; PATNAIK et al., 2005b). For neuroendocrine neoplasms, it was recommended to examine more than one type of neurosecretory product by IHC examination, as there was a wide variation in the expression of these products in the biliary epithelium. (CULLEN, 2017). Carcinoid of the gallbladder should be differentiated from other neoplasms that affect this organ (CULLEN, 2017). In the present cases, neoplasm of ductal epithelial origin was excluded due to histological characteristics and particularly by the absence of immunoreactivity for CK7. Gallbladder adenocarcinomas are composed of epithelial cells, with formation of acinar and tubular structures separated by a thin fibrous stroma. In well-differentiated tumors, neoplastic cells are similar to normal bile epithelium, and as they become undifferentiated, a solid pattern is more predominant. Furthermore, biliary epithelium neoplasms were characterized by a high mitotic index, desmoplasia and mucin production (PATNAIK et al., 1981; CULLEN, 2017).

The diagnosis of carcinoid in the gallbladder in the present report was based on pathological findings, particularly the IHC analysis using antibodies for NSE and for specific neurosecretory products. Carcinoid gallbladder is a rare neoplasm in dogs, without specific clinical signs, but should be included in the differential diagnosis of lesions affecting this organ.

\section{ACKNOWLEDGEMENTS}

This work was supported by Conselho Nacional de Desenvolvimento Científico e Tecnológico (CNPq), and it was financed in part by the Coordenação de Aperfeiçoamento de Pessoal de Nível Superior (CAPES). Brasil - Finance code 001.

\section{DECLARATION OF CONFLICT OF INTERESTS}

The authors declare no conflict of interest. The founding sponsors had no role in the design of the study; in the collection, analyses, or interpretation of data; in the writing of the manuscript, and in the decision to publish the results.

\section{AUTHORS' CONTRIBUTIONS}

All authors contributed equally for the conception and writing of the manuscript. All authors critically revised the manuscript and approved of the final version. 


\section{REFERENCES}

ALLISON, R.W. Laboratory evaluation of the liver. In: THRALL, M.A. et al. (Eds). Veterinary hematology and clinical chemistry. 2.ed. Iowa: John Wiley \& Sons, Inc Lippincott Williams \& Wilkins, 2012. Cap.26, p.401-424.

BIRETTONI, F. et al. Primary neuroendocrine carcinoma of the gallbladder in a dog. Veterinary Research Communications v.32, n.1, p.239-242, 2008. Available from: <https:/www.ncbi. nlm.nih.gov/pubmed/18688739>. Accessed: Nov. 03, 2018. doi: 10.1007/s11259-008-9151-x

CREUTZFELDT, W. Carcinoid tumors: development of our knowledge. World Journal of Surgery, v.20, p.126-131, 1996. Available from: $<$ https://www.ncbi.nlm.nih.gov/pubmed/8661807>. Accessed: Nov. 03, 2018. doi: 10.1007/s002689900020.

CULLEN, J.M. Tumors of the liver and gallbladder. In: MEUTEN, D.J. (Ed). Tumors in domestic animals. 5.ed. Iowa: John Wiley \& Sons Inc, 2017. Cap. 14, p.602-631.

ERICKSON, L.A.; LLOYD, R.V. Practical markers used in the diagnosis of endocrine tumors. Advances in Anatomic Pathology, v.11, p.175-189, 2004. Available from: <https://www. ncbi.nlm.nih.gov/pubmed/15220821>. Accessed: Nov. 05, 2018. doi: 10.1097/01.pap.0000131824.77317.a7.

HAMILTON, S.R. et al. Neoplasms. In: RUBIN, E.; FARBER, J.L. (Eds). Pathology. 3.ed. Philadelphia: Lippincott-Raven, 1999, p. $720-721$.

KAZUYOSHI, N. et al. Composite glandular-endocrine cell carcinoma of the extrahepatic bile duct: immunohistochemical study. Pathology, v.25, p.90-94, 1993. Available from: <https:// www.ncbi.nlm.nih.gov/pubmed/8316508>. Accessed: Nov. 10, 2018. doi: 10.3109/00313029309068910.

LIPPO, N.J. et al. Acute hemobilia and hemocholecyst in 2 dogs with gallbladder carcinoid. Journal of Veterinary Internal Medicine, v.22, p.1249-1252, 2008. Available from: <https:// www.ncbi.nlm.nih.gov/pubmed/18673422>. Accessed: Nov. 10, 2018. doi: 10.1111/j.1939-1676.2008.0156.x.

MODLIN, I.M. et al. A 5-decade analysis of 13,715 carcinoid tumors. Cancer, v.97, p.934-959, 2003. Available from: <https:// www.ncbi.nlm.nih.gov/pubmed/12569593>. Accessed: Nov. 10, 2018. doi: $10.1002 /$ cncr. 11105 .

MORRELL, C.N. et al. A carcinoid tumor in the gallbladder of a dog. Veterinary Pathology, v.39, p.756-758, 2002. Available from: $<$ https://www.ncbi.nlm.nih.gov/pubmed/12450211>. Accessed: Nov. 05, 2018. doi: 10.1354/vp.39-6-756.

NISHIGAMI, T. et al. Carcinoid tumor of the gall bladder. Internal Medicine, v.35, p.953-956, 1996. Available from: <https://www. ncbi.nlm.nih.gov/pubmed/9030993>. Accessed: Nov. 15, 2018. doi: 10.2169/internalmedicine.35.953

PATNAIK, A.K. et al. Canine hepatic carcinoids. Veterinary Pathology, v.18, p.445-453, 1981. Available from: <https://www. ncbi.nlm.nih.gov/pubmed/7257087>. Accessed: Nov. 10, 2018. doi: $10.1177 / 030098588101800404$.

PATNAIK, A.K. et al. Hepatobiliary neuroendocrine carcinoma in cats: a clinicopathologic, immunohistochemical, and ultrastructural study of 17 cases. Veterinary Pathology, v.42, p.331-337, 2005a. Available from: <https://www.ncbi.nlm.nih. gov/pubmed/15872379>. Accessed: Nov. 10, 2018. doi: 10.1354/ vp.42-3-331.

PATNAIK, A.K. et al. Canine hepatic neuroendocrine carcinoma: an immunohistochemical and electron microscopic study. Veterinary Pathology, v.42, p.140-146, 2005b. Available from: $<$ https://www.ncbi.nlm.nih.gov/pubmed/15753467>. Accessed: Nov. 10, 2018. doi: 10.1354/vp.42-2-140.

SAKO, T. et al. Immunohistochemical evaluation of a malignan intestinal carcinoid in a dog. Veterinary Pathology, v.40, p.212215, 2003. Available from: <https://www.ncbi.nlm.nih.gov/ pubmed/12637763>. Accessed: Nov. 10, 2018. doi: 10.1354/ vp.40-2-212.

TURNER, J.R. O trato gastrointestinal. In: KUMAR, V. et al. Robbins e Cotran, Bases patológicas das doenças. 8.ed. Rio de Janeiro: Elsevier, 2010. Cap. 17, p.795-797.

WILLARD, M.D. et al. Neuroendocrine carcinoma of the gallbladder in a dog. Journal of the American Veterinary Medical Association, v.192, p.926-928, 1988. Available from: $<$ https://www.ncbi.nlm.nih.gov/pubmed/3366681>. Accessed: Nov. 10, 2018. 